Nippon Suisan Gakkaishi $\quad$ 82(5), 807 (2016)

\title{
シンポジウム記録 地下水・湧水を介した陸一海のつながり
}

\section{I -2. 陸域の地形および地下水流動に基づく 海底湧水の評価}

齋藤光代, ${ }^{1}$ 小野寺真一, ${ }^{2}$ 清水裕太 ${ }^{3}$

1 岡山大学大学院環境生命科学研究科,

2 広島大学大学院総合科学研究科,

${ }^{3}$ 日本学術振興会特別研究員 PD,

(国研) 農研機構 近畿中国四国農業研究センター

I -2. Evaluation of submarine groundwater discharge (SGD) based on the coastal topography and groundwater flow

Mitsuyo SAITO, ${ }^{1}$ SHIN-ICHI ONODERA ${ }^{2}$

AND YUTA SHIMIZU ${ }^{3}$

${ }^{1}$ Graduate School of Environmental and Life Science, Okayama University, Kita, Okayama 700-8530, ${ }^{2}$ Graduate School of Integrated Arts and Sciences, Hiroshima University, Higashi-hiroshima, Hiroshima 739-8521, 3JSPS PD, National Agriculture and Food Research Organization Western Region, Agricultural Research Center, Fukuyama, Hiroshima 721-8514, Japan

海岸地域の地下では海水と陸側の淡水地下水との間に 塩淡境界が形成されるが，降雨一浸透-流動-流出の一連 の水循環によって形成される地下水流動系により，この 塩淡境界は海岸線よりも沖合抢よび海底地下深くに押し 出され, 淡水地下水の海底涌水 (Submarine Groundwater discharge: SGD，これ以降は SGD）が生じる。1) 一般に，地下水の流量はダルシーの法則 $(\mathrm{q}=-\mathrm{K}(\Delta \mathrm{h}$ /L)）に基づく推定が可能であり，大まかに地下の透水 性 ( $\mathrm{K}$ : 透水係数) と地下水の勾配 $(\Delta \mathrm{h} / \mathrm{L}$ : 動水勾配) によって決定されるといえる。

実測に基づく SGD 評価の例として, Onodera et al. ${ }^{2)}$ はピエゾメーター法（中空のパイプの側面にスリットを 開けた簡易の井戸を多地点・深度別に埋設し，地下水の 採水抢よび水位測定を行う方法）により，瀬戸内海の島 嶼部沿岸を対象に潮位変化にともなうSGD のパターン を明らかにするとともに，特に SGD によるリンの輸送 が顕著に生じていることを明らかにした。またここよよ うな SGD によるリンの供給は, 大阪湾沿岸等において も無視できないことが報告されている。3)

一方で, 沿岸域の地形情報に基づき SGDをより広域
で推定しようとする試みも行われてきた。4) 清水ほか55 は, 沿岸域の地下水の動水勾配が地形勾配に依存すると いう関係性を踏をえ, 瀬戸内海の備讃瀬戸を対象に GIS 地形モデルによるSGD の空間分布評価を行い，背後の 地形勾配が急な海岸線では SGD が大きくなり, 対照的 に埋立て地等の地形が平坦なエリアでは小さくなる傾向 を示しており，同モデルを大阪湾沿岸に適用した場合に も同様の結果を得ている。防ただし，大阪のような都市 部の場合は沿岸域の開発による地形勾配の減少に限ら ず，地下水の過剩揚水による水位低下も SGD を減少さ せる一因となり，このような現象はアジアの大都市であ るバンコクやジャカルタ等で確認されている。6)

以上を踏をえると, 人間活動の影響が顕著な都市部等 を除いては, 降水量が多く背後の地形勾配が急なエリア に扔いて，SGDは相対的に大きくなる傾向にあると考 えられる。ただし, 地下の地質構造（透水性や亀裂の有 無等）も重要なファクターである。近年では国内外にお いてSGD と沿岸生態系・水産資源との関係が注目され て抢り，今後は多様な地域に抢ける SGD 評価事例の蓄 積に加え, 前述のような陸域の地形情報等を基にした広 域での推定と水産資源・生物多様性との対応関係に関す る考察も重要になると考えられる。

\section{文献}

1) Freeze RA, Cherry JA. Groundwater. Prentice Hall, Upper Saddle River. 1979.

2) Onodera S, Saito M, Hayashi M, Sawano M. Nutrient dynamics with groundwater-seawater interactions in a beach slope of a steep island, western Japan. IAHS Publ. 2007; 312: $150-158$.

3）小野寺真一, 清水裕太, 有本弘孝, 中屋眞司. 大阪湾への 地下水による栄養塩流出とその長期変動に関する評価. 瀬 戸内海, 2010; 60: 62-65.

4) Bokuniewicz H, Buddemeier R, Maxwell B, Smith C. The typological approach to submarine groundwater discharge (SGD). Biogeochem. 2003; 66: 145-158.

5）清水裕太, 小野寺真一, 齋藤光代. $50 \mathrm{~m}$ メッシュ標高情 報と GIS を利用した海底地下水流出量の空間分布評価一 瀬戸内海中央部での適用例一. 陸水学雑誌 2009; 70: 129 -139 .

6) Onodera S, Saito M, Sawano M, Hosono T, Taniguchi M, Shimada J, Umezawa Y, Lubis RF, Buapen S, Delinom R. Effects of intensive urbanization on the intrusion of shallow groundwater into deep groundwater: Examples from Bangkok and Jakarta. Sci. Total Environ. 2009; 407: 32093217. 